УДК 623.746.352

Вадим Володимирович Лук'янчук (кандидат технічних наук, с.н.с) ${ }^{1}$

Іван Михайлович Ніколаєв (кандидат технічних наук, с.н.с) ${ }^{1}$

Павло Вікторович Опенько (кандидат технічних наук)

Юрій Анатолійович Дзюбенко (кандидат військових наук, доцент)

${ }^{1}$ Харківський національний університет Повітряних Сил імені Івана Кожедуба, м. Харків

${ }^{2}$ Національний університет оборони Украӥни імені Івана Черняховського, Київ, Україна

\title{
ШЛЯХИ І ПРИНЦИПИ РОЗВИТКУ ТЕХНОЛОГІЧНОГО БАЗИСУ ЗЕНІТНОГО РАКЕТНОГО ОЗБРОЄННЯ
}

На основі аналізу світових тендениій розвитку технологій обтрунтовується структура технологічного базису, необхідного для створення і виробництва в Украӥні сучасних систем (комплексів) зенітного ракетного озброєння. Показано, щчо основу цьього технологічного базису складають сукупності продуктових і виробничих технологій, які визначають обрис складових частин (бойових $і$ технічних засобів) зенітного ракетного озброєння, мають складну структуру і базуються на досягненнях науковотехнічного прогресу у різних галузях знань. Наведені принципи розвитку технологічного базису $i$ визначені критичні технології, розвиток яких дозволить створити науково-технологічні заділи, які можуть бути покладені в основу розробки і виробництва в України перспективних систем (комплексів) зенітного ракетного озброєння наступного покоління.

Ключові слова: зенітне ракетне озброєння; технологічний базис; макротехнологія; продуктова технологія; виробнича технологія; критична технологія; науково-технологічний заділ.

\section{Вступ}

Постановка проблеми. Аналіз досвіду сучасних військових конфліктів показує, що системи (комплекси) зенітного ракетного озброєння (ЗРО) у першій четверті XXI століття будуть складати основу бойової мощі угрупувань протиповітряної оборони (ППО) важливих адміністративних, промислових i військових об'єктів від ударів засобів повітряного нападу (ЗПН) противника [1]. Виходячи 3 цього, технологічно розвинені країни (США, Росія, Великобританія, Франція, Китай, Ізраїль, Південна Корея) активно розробляють системи (комплекси) ЗРО нового покоління. Основною тенденцією їх розвитку є підвищення ефективності боротьби 3 тактичними балістичними та крилатими ракетами, засобами високоточної зброї i нарощування можливостей зі знищення малопомітних аеродинамічних цілей $[2,3]$. Найбільших успіхів у сфері ЗРО досягли США і Росія, які здатні здійснювати розробку i виробництво зенітних ракетних систем (комплексів) різного функціонального призначення [4]. До них належать ЗРК сімейства «Patriot», ЗРС С-300ПМУ, С-300BM, С-350, С-400, С-500. Країни Західної Європи (Великобританія, Франція, Італія, ФРН, Норвегія, Швейцарія, Швеція) ведуть коопераційні програми зі створення сучасних систем (комплексів) ЗРО. Так, наприклад, США, наряду з удосконаленням ЗРК сімейства «Patriot» у даний час ведуть розробку комплексу THAAD та у кооперації з Німеччиною та Італією - розробку ЗРК MEADS, у якому передбачається використовувати ракети РАС-3. Франція, Німеччина та Італія ведуть розробку ЗРК SAMP/T iз ЗКР «Aster 30».

Сучасний етап розвитку систем (комплексів) ЗРО в провідних зарубіжних країнах здійснюється при потужній економічній підтримці держави на основі широкого використання нових знань i наукомістких технологій. При цьому ряд фахівців припускає, що широкомасштабне впровадження нових технологій змінить технічний обрис систем (комплексів) ЗРО нового покоління.

В Україні у зв'язку з різким зниженням державних асигнувань на дослідження і розробки у сфері ЗРО скоротилася кількість і масштабність науково-дослідних і дослідно-конструкторських робіт (НДДКР), що призводить до відставання від найбільш розвинених країн Заходу $[5,6]$. У цих умовах пріоритетним шляхом створення ЗРО $€$ пріоритетний розвиток наукового потенціалу України в напрямах, що визначатимуть технологічний обрис перспективних систем (комплексів) 3РО. Реалізація цієї стратегії вимагає залучення значних ресурсів на проведення досліджень і створення нових технологій i виробництв, при цьому їх фінансування зв'язане 3 високим рівнем ризику. Обмеженість фінансових 
ресурсів обумовлює необхідність обгрунтованого вибору раціональної кількості найбільш ефективних технологій для їх розвитку i впровадження в перспективні системи (комплекси) ЗРО. У зв'язку 3 цим, актуальним $є$ аналіз сучасного стану i перспектив розвитку технологічного базису, необхідного для створення і виробництва в Україні систем (комплексів) ЗРО нового покоління.

Аналіз останніх досліджень і публікацій. Аналіз відомих публікацій в спеціалізованих науково-технічних виданнях показав, що питанням розвитку новітніх технологій створення озброєння та військової техніки (ОВТ) в провідних країнах світу приділяється особлива увага. У монографіях $[7,8]$ розглянуті проблеми розвитку військових технологій у XXI столітті, питання удосконалення програмно-цільового планування i управління створенням науково-технічного заділу для перспективного i нетрадиційного озброєння. У аналітичному огляді [9] наведені перелік, характеристики, стан, перспективи розвитку i реалізації критичних технологій в США и країнах ЕС. В [10] досліджуються питання розвитку пріоритетних технологій подвійного призначення в США, Великобританіі, Японії, Китаї, Німеччині, Франції, Ізраїлі та Індії. В [11] наведений прийнятий у Росії перелік базових (критичних) технологій, а також визначено поняття "науковотехнічний заділ" як "накопичення знань, технологій, виробів, напівфабрикатів та інших видів продукції понад потреби". Показано, що основними елементами науково-технічного заділу є науковий, науково-технологічний і виробничо-технологічний заділи. В [12] аналізується стан і стратегія спільного розвитку вітчизняної мікроелектроніки і радіоелектроніки. В [13] наведені пропозиції щодо вдосконалення науково-методичного апарату обгрунтування складу НДДКР 3 розвитку радіолокаційних технологій на основі побудови структурних функціонально-технологічних схем перспективних зразків радіолокаційного озброєння. В [14] розглянуті проблемні аспекти розвитку технологій, орієнтованих на створення i застосування перспективних засобів збройної боротьби. В [15] аналізуються критичні технології, як інструмент забезпечення обороноздатності України.

В той же час у відомій науково-технічній літературі відсутні публікації, в яких розглядаютья питання формування технологічного базису, необхідного для створення сучасних і перспективних систем (комплексів) ЗРО.

Метою статті $\epsilon$ визначення структури i основних тенденцій розвитку технологічного базису систем (комплексів) ЗРО, як найбільш складних i науковомістких виробів військової техніки, при створенні яких використовується широкий спектр критичних військових технологій.

\section{Виклад основного матеріалу дослідження}

Створення систем (комплексів) ЗРО нового покоління можливе при наявності у держави високорозвиненого технологічного базису, основу якого складають сукупність найбільш важливих технологій, необхідних для створення усієї номенклатури перспективних зенітних ракетних систем (комплексів) різного цільового призначення. Це обумовлює необхідність визначення пріоритетних напрямів розвитку в Україні технологічної бази створення i виробництва ЗРО нового покоління.

Досвід розвинених країн світу свідчить, що в основу розвитку технологічного базису ЗРО, слід покласти розробку базових (критичних) військових технологій i створення науковотехнічного заділу у різних галузях науки і техніки. У розвинених країнах світу своєчасне створення науково-технічного заділу служить предметом особливої турботи держави. При цьому задільна фаза поглинає в цих країнах приблизно 10\% від загальних бюджетних витрат на розвиток ЗРО. Досвід США свідчить, що завчасне створення необхідних технологій у формі науково-технічного заділу сприяє зменшенню витрат і скороченню термінів створення нових зразків ОВТ [9-11].

Сукупність технологій, що використовуються при створенні сучасного ЗРО, поділяються на продуктові i виробничі. Під продуктовими технологіями розуміють сукупності знань i документованих даних про принципи побудови та конструктивні, функціональні і експлуатаційні особливості конкретних систем (комплексів) $3 \mathrm{PO}$ та їх складових частин як виробів військової техніки, що мають певні бойові властивості та відповідні тактико-технічні характеристики (ТTX). Виробничі технології описують різні види технологічних процесів, які використовуються при виготовленні конкретних систем (комплексів) ЗРО, їх складових частин, функціональних вузлів, комплектуючих виробів та елементної конструкторської бази. Як продуктові, так i виробничі технології, необхідні для створення i виробництва сучасних та перспективних систем (комплексів) ЗРО, є складними об'єктами.

Для зручності аналізу тенденцій розвитку усе різноманіття технологій, які використовуються при створенні ЗРО, доцільно розбити на три групи:

1) технології створення i виробництва конкретних комплексів (систем) ЗРО та їх складових частин;

2) технології створення i виробництва функціональних систем, комплектуючих виробів та інших конструктивних елементів для систем (комплексів) 3РО та їх складових частин; 
3) технології створення i виробництва ЕКБ, нових матеріалів і речовин.

Першу групу складають технології, що описують конструктивно-технологічні особливості i способи бойового застосування систем (комплексів) ЗРО конкретного цільового призначення. Ці технології $\epsilon$, по суті, макротехнологіями, які включати в себе інші, так звані вкладені технології, склад і взаємозв'язки яких визначають архітектуру цих технологій в цілому [19].

Структурними компонентами макротехнологій $\epsilon$ технології, що описують принципи побудови, функціонування, способи бойового застосування та створення складових частин 3РО, до яких відносяться:

1) зенітні керовані ракети;

2) пускові пристрої (установки);

3) оглядові та стрільбові РЛС;

4) пункти управління;

5) допоміжні технічні засоби. До складу цих технологій в якості структурних елементів входять технології другої та третьої груп.

До другої групи відносяться технології, що описують конструкцію, функціонування, застосування i виробництво функціональних систем, комплектуючих виробів та інших конструктивних елементів для сучасних та перспективних систем (комплексів) ЗРО конкретного цільового призначення. До них відносяться технології створення антенних, передавальних та приймальних систем РЛС, їх функціональних вузлів, засобів обчислювальної техніки, засобів зв'язку, електроживлення, засобів рухомості та інші технологіі.

До третьої групи відносяться технології, що є сукупністю документованих даних і знань в галузі мікро- та наноелектроніки, оптоелектроніки i лазерної техніки, комп'ютерних та інформаційних технологій, нових матеріалів і речовин.

Структура технологічного базису створення i виробництва перспективних систем (комплексів) ЗРО, якій складається 3 перерахованих груп технологій, наведена на рис. 1.

Особливе місце у технологічному базису сучасного ЗРО займають технології створення i виробництва зенітних керованих ракет (ЗКР). Задоволення вимог щодо кардинального підвищення точності наведення ЗКР і зниження їх маси $з$ одночасним збільшенням дальності і висоти ураження цілей може бути досягнуте за рахунок застосування нових ключових технологій, що забезпечують якісно вищі рівні інформаційності і маневреності ЗКР завдяки прогресу в створенні малогабаритних активних

головок радіолокаційного самонаведення, бортових інерціальних систем, бортових комп'ютерів і ракетних двигунів управління [16-18]. Застосування нових ключових технологій на борту
ЗКР дозволяє об'єднати в єдину управляючу систему інформаційні і обчислювальні засоби газодинамічні і аеродинамічні пристрої управління. При цьому завдання управління вирішується на борту ЗКР, а радіолокатор системи (комплексу) ЗРО стає джерелом інформації про координати i швидкість цілі (можливо, про координати і швидкість ЗКР на початковій фазі польоту), яка передається на борт ЗКР по радіолінії.

\begin{tabular}{|c|c|}
\hline 6 & $\begin{array}{c}\text { Макротехнології систем (комплексів) } \\
\text { ЗРО як виробів військової техніки }\end{array}$ \\
\hline 5 & $\begin{array}{c}\text { Технології платформ, на яких розміщу- } \\
\text { ються функціональні системи і пристрої }\end{array}$ \\
\hline 4 & Технології функціональних систем \\
i пристроїв
\end{tabular}

Рис. 1. Структура технологічного базису ЗРО

ЗКР, призначені для боротьби з високоточною зброєю, крилатими ракетами i балістичними цілями, повинні підривати їх бойову частину для виключення iі падіння на об'єкт, що захищається. Для досягнення цього результату потрібне пряме попадання ЗКР. Потенційна можливість кінетичного ураження цілі шляхом прямого попадання може бути забезпечена шляхом впровадження режиму надманевреності ЗКР, який реалізується газодинамічним способом створення сил і моментів. На сучасних ракетах цей режим реалізується за допомогою двигунів поперечного управління i наведення, що розташовуються поблизу центру мас i служать для усунення помилки на кінцевій ділянці польоту. Надманеврені ЗКР з газодинамічним управлінням володіють часом реакції в 10-20 разів меншим, а перевантаженнями на граничних висотах польоту в 10-20 разів більшими, ніж ЗКР 3 традиційним аеродинамічним способом створення сил i моментів.

Досвід провідних країнах світу свідчить, що в основу створення технологічного базису ЗРО в Україні повинні бути покладені принципи, які 
характеризують найбільш загальні риси обрису перспективних систем (комплексів) цього виду озброєння. До цих принципів належать:

- базово-модульний принцип побудови систем (комплексів) 3РО, реалізація якого дозволяє при мінімальному типажі (базовому наборі) засобів (модулів) формувати різні за призначенням зенітні ракетні системи (комплекси);

- принцип оперативної реконфігурації систем (комплексів) ЗРО, реалізація якого дозволяє забезпечити високу ефективність і бойову стійкість перспективних систем (комплексів) ЗРО в умовах прогнозованого вогневого i радіоелектронного подавлення противника залежно від оперативно-тактичної обстановки, що складається;

- принцип багатофункціональності систем (комплексів) ЗРО, який полягає в можливості боротьби 3 різними типами цілей: аеродинамічними (в т. ч. що знаходяться за лінією радіогоризонту), аеробалістичними

балістичними;

- принцип міжвидової і внутрішньосистемної уніфікації, що дозволяє скоротити номенклатуру ЗРО, що розробляється, та забезпечити можливість застосування в зенітних ракетних військах, військовій ППО і ВМС одних і тих же ракет, обчислювальних засобів, засобів зв'язку, електроживлення, уніфікованих типових елементів і пристроїв. При цьому необхідний тип шасі для засобів ЗРО визначається, виходячи 3 фізикогеографічних особливостей району можливого застосування, розвиненості дорожньої мережі та інших чинників;

- принцип мобільності, реалізація якого забезпечує можливість ведення частинами i підрозділами, оснащеними перспективними системами (комплексами) ЗРО, маневрених бойових дій без втрати зв'язку i управління, розгортання в бойовий порядок 3 маршу на непідготовлених позиціях і приведення їх в бойову готовність без прокладення кабельних ліній зв'язку і електроживлення;

- принцип мережевої структури побудови системи управління, реалізація якого забезпечує отримання інформації від різних джерел і обмін даними між споживачами системи, а також своєчасну видачу цілевказівки на необхідні засоби ураження і протидії в реальному масштабі часу;

- принцип інтеграції перспективних систем (комплексів) ЗРО із засобами РЕБ, авіаційними комплексами ППО;

- принцип забезпечення високої експлуатаційної надійності перспективних систем (комплексів) ЗРО упродовж усього терміну служби.

Можливість реалізації цих принципів у конкретному зразку ЗРО оцінюється на етапі зовнішнього проектування за допомогою системи математичного моделювання, яка дозволяє формувати обрис перспективних систем (комплексів) ЗРО відповідно до їх цільового призначення, оцінювати їх основні ТTХ та обрис i TTX їх бойових i технічних засобів, обгрунтовувати обрис i льотно-технічні характеристики ЗКР (у тому числі за рахунок впровадження технології електронних пусків), оцінювати показники бойової ефективності в прогнозованих умовах ведення бойових дій 3 урахуванням вогневої і радіоелектронної протидії повітряного противника.

Використання системи математичного моделювання дозволяє за допомогою відповідних моделей оцінювати можливість i ефективність застосування таких технічних рішень, як використання активних ФАР; уніфікація приймальних і передавальних модулів, пристроїв обробки сигналів, комп'ютерів, робочих місць, шасі; автоматизація процесів бойової роботи, функціонального контролю i пошуку несправностей; застосування базово-кореляційних методів визначення координат постановників активних перешкод; застосування методу інерціального наведення ЗКР у сполученні 3 високоточним газодинамічним управлінням на кінцевій ділянці траєкторії.

Технічний рівень сучасних систем (комплексів) ЗРО у значній мірі залежить від номенклатури i параметрів елементної конструкторської бази (ЕКБ), виробництво якої в Україні практично відсутнє. Тому одним 3 актуальних питань $\epsilon$ відновлення технологічної бази ЕКБ. Пріоритетними напрямами у цій галузі слід вважати розробку i освоєння у виробництві надвисокочастотної техніки, радіаційно-стійкої ЕКБ, мікросистемної техніки, мікроелектроніки, електронних матеріалів i структур, створення уніфікованих електронних модулів, типових базових технологічних процесів.

Аналіз існуючого науково-технологічного потенціалу свідчить про те, що в Україні для створення систем (комплексів) ЗРО потенційні розробники використовують науково-технічні заділи, які розроблені ще у радянські часи [12]. При цьому не приділяється достатньої уваги проведенню досліджень у напряму створення сучасного науково-технологічного заділу, який може бути використаний для розробки i виробництва перспективних систем (комплексів) ЗРО конкретного цільового призначення. Одним 3 шляхів вирішення цього питання $\epsilon$ визначення i затвердження на державному рівні переліку критичних технологій, що дозволить сконцентрувати існуючі фінансові і матеріальні ресурси на найбільш пріоритетних напрямах національного технологічного розвитку ЗРО.

Під критичними розуміються технології, які забезпечують істотний приріст тактико-технічних 
характеристик (ТТХ) систем (комплексів) ЗРО або значне зниження необхідних ресурсних витрат на ï розробку або модернізацію [9]. Досвід розвинених країн свідчить, що до переліку критичних технологій, розробка яких дозволить Україні істотно просунуться на шляху створення сучасного технологічного базису у сфері ЗРО, доцільно віднести:

- у сфері радіолокації та радіолокаційної техніки:

1) генерування, випромінювання i прийом широкосмугових зондуючих сигналів 3 внутрішньо-імпульсною лінійно-частотною модуляцією i фазо-кодовою маніпуляцією, сигналів, що дискретно-кодуються по частоті, багаточастотних сигналів, наддовгих i надкоротких сигналів;

2) створення антенних систем 3 активними фазованими антенними решітками (АФАР);

3) впровадження базово-кореляційних методів визначення координат постановників активних радіоперешкод;

4) впровадження адаптивних алгоритмів обробки радіолокаційної інформації для оптимального виявлення і вимірювання координат цілей;

5) уніфікація приймальних i передавальних модулів, пристроїв обробки сигналів, обчислювальних засобів, робочих місць;

- у сфері ракетобудування:

1) створення високошвидкісних ЗКР 3 інерційно-активним наведенням та високоточним газодинамічним управлінням на кінцевій ділянці траєкторії;

2) розробка активно-напівактивних радіолокаційних та багатоспектральних оптикоелектронних ГСН;

- у сфері інформаційних технологій: 1) автоматизація процесів бойової роботи, контролю технічного стану та пошуку місця відмов; 2) створення високошвідкістних цифрових обчислювальних комплексів;

- у сфері телекомунікаційних технологій створення систем зв'язку і передачі даних при реалізації принципів їх мережевої побудови;

- у сфері створення нових матеріалів i комплектувальних виробів - створення i виробництво нової ЕКБ, кристалічних матеріалів, мікросистемної техніки, композиційних і керамічних матеріалів, металів i сплавів iз спеціальними властивостями.

Організація i проведення досліджень у перелічених сферах вимагає істотного зростання витрат на НДДКР, створення необхідної науковотехнологічної бази. Тому актуальним є формування раціонального переліку критичних технологій, розробка яких забезпечить створення перспективних систем (комплексів) ЗРО в умовах фінансових i ресурсних обмежень. Для обгрунтування такого переліку необхідно мати відповідний методичний апарат.

В основу розробки такого апарату може бути використана ідеологія функціональнотехнологічних особливостей систем (комплексів) ЗРО, яка передбачає представлення їх у вигляді “типових зразків” і структурних функціональнотехнологічних схем (СФТС) [13]. При такому підході будь-яка система ЗРО може бути описана “типовим зразком", який має максимальну функціональну і структурну спільність з системами (комплексами) ЗРО певної групи.

Аналіз структури сучасних систем (комплексів) ЗРО свідчить, що типовий зразок ЗРО може бути представлений $\mathrm{y}$ вигляді сукупності функціонально пов'язаних елементів, до яких відносяться:

а) базовий носій - колісне або гусеничне шасі будь-якої конфігурації, призначене для застосування в різних середовищах;

б) бойові засоби, призначені для виявлення $\mathrm{i}$ знищення ЗПН;

в) засоби забезпечення i обслуговування, призначені для підготовці до застосування i технічної експлуатації зразка ЗРО.

Склад бойових засобів зразка ЗРО конкретного типа встановлюється, виходячи 3 його функціонального призначення і може включати [2]:

1) пункти бойового управління;

2) оптико-електронні i/aбо радіолокаційні засоби розвідки ЗПН, які працюють у різних діапазонах хвиль (метровому, дециметровому, сантиметровому або міліметровому);

3) один або декілька типів ЗКР, які розміщуються у ТПК;

4) оптико-електронні i/aбо радіолокаційні засоби наведення ЗКР на цілі;

5) багатозарядні пускові установки (пристрої). Важливими елементами цих засобів $є$ навігаційні пристрої, засоби зв'язку, спеціалізовані обчислювачі 3 програмно-алгоритмічним забезпеченням, автономні засоби електроживлення.

СФТС, сформована 3 урахуванням структури системи (комплексу) ЗРО, що пропонується для розробки (модернізації), є основою для формування раціонального варіанту НДДКР 3 розробки необхідних технологій.

При наявності сформованої СФТС системи (комплексу) 3РО для відбору необхідних технологій можуть бути використані методи багатокритерійної колективної експертизи. Найбільш відомим серед цих методів є метод аналізу ієрархій (MAI), розроблений Т. Сааті. У загальному випадку цей метод включає наступні етапи:

1) підготовка початкових даних;

2) формування груп експертів по кожному науково-технологічному напряму, проведення 
анкетування або опитування і формування бази експертних оцінок;

3) побудова матриці безпосередніх оцінок критичних технологій;

4) аналіз отриманих результатів.

Схема відбору технологій для їх реалізації на етапах розробки і постановки на виробництво виробів ЗРО наведена на рис. 2.

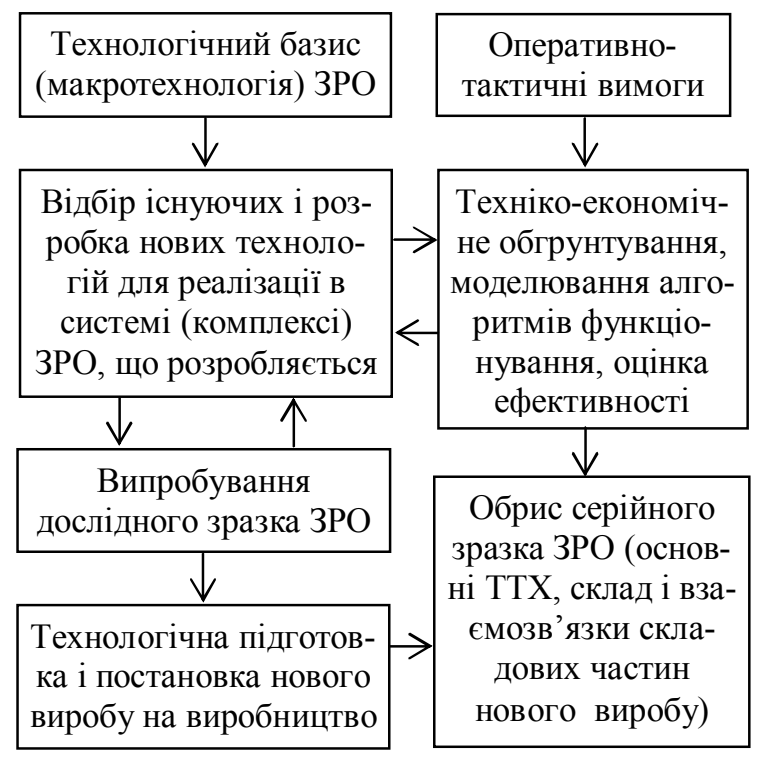

Рис. 2. Схема відбору технологій на етапах розробки і постановки на виробництво виробів ЗРО

Кількісний аспект витрат на розвиток технологічного базису ЗРО в Україні може бути сформульований у вигляді оптимізаційної задачі таким чином 3 безлічі можливих технологій необхідно вибрати такий перелік критичних технологій, який би забезпечив виконання завдань ППО $з$ ефективністю, не нижче потрібної, при мінімальних витратах (втратах) сил і засобів на розробку і виробництво потрібної кількості систем (комплексів) ЗРО різного цільового призначення:

$$
\hat{\mathrm{j}}=\arg \min _{\mathrm{j}=1,2, . ., \mathrm{m}} \varphi\left(\mathrm{C}_{\mathrm{j}}, \mathrm{N}_{\mathrm{j}}, \mathrm{S}_{\mathrm{j}}\right)
$$

при

$$
\ni\left(C_{j}, N_{j}, S_{j}\right) \geq Э_{т р}
$$

де: $\mathrm{C}_{\mathrm{j}}-$ фінансові витрати на реалізацію $\mathrm{j}$-го варіанту переліку критичних технологій;

\section{Лimepamypa}

1. Ненартович Н. Э. Современные зенитные ракетные системы ПВО и нестратегической ПРО// Информационно-аналитическое издание "Воздушнокосмическая оборона”, 2010. 2. Коровин А. Н. Ракетные комплексы ПВО: тенденции развития. https://topwar.ru/2217-raketnye-kompleksy-pvo-tendenciirazvitiya.html. 3. Алексеев П., Данилов О. Состояние и перспективы развития зарубежных ЗРК большой и средней дальности // Зарубежное военное обозрение. 2006. № 11. C. 35- 43. http://militaryarticle.ru/zarubezhnoevoennoe-obozrenie/2006-zvo/7419-sostojanie-i-perspektivy-
$\mathrm{N}_{\mathrm{j}} \quad$ - кількість систем (комплексів) ЗРО, в яких може бути використаний j-й варіант переліку критичних технологій;

$\mathrm{S}_{\mathrm{j}}$ - витрати на розробку $\mathrm{i}$ виробництво потрібної кількості систем (комплексів) ЗРО при $\mathrm{j}-\mathrm{y}$ варіанті переліку критичних технологій;

$\ni\left(\mathrm{C}_{\mathrm{j}}, \mathrm{N}_{\mathrm{j}}, \mathrm{S}_{\mathrm{j}}\right)$ - показник ефективності угрупування ЗРВ при $\mathrm{j}-\mathrm{y}$ варіанті переліку критичних технологій;

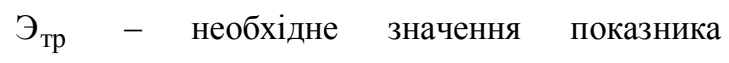
ефективності угрупування ЗРВ.

\section{Висновки й перспективи подальших досліджень}

1. Проведений аналіз свідчить, що без опори на новітні технології не може бути забезпечене подальше істотне просування України на шляху розвитку перспективних систем (комплексів) ЗРО, ефективність яких не поступається найкращим світовим зразкам.

Для вирішення цього завдання необхідно:

a) забезпечити ефективне використання i нарощування науково-технічного заділу в області технологій ракетобудування, радіолокації, інформатики, обчислювальної техніки та інших “проривних” технологій, що дозволяють створити нову матеріальну базу для розвитку ОВТ ЗРВ Повітряних Сил ЗС України;

б) відновити або розгорнути необхідні виробничі потужності в сфері мікроелектроніки, приладів надвисокої частоти, ракетних палив i вибухових речовин, спеціальних матеріалів для ракет і пускових установок;

в) створити кооперацію підприємств, наукових колективів, технологічної і експериментальної бази, яка має забезпечити модернізацію, розробку i виробництво вітчизняних зразків ЗРО.

2. Для обгрунтування пріоритетних напрямів розвитку в Україні технологічного базису у сфері створення і виробництва ЗРО нового покоління потрібні адекватний науково-методичний апарат, нормативно-методичне і нормативно-правове забезпечення. Розробка такого апарату є одним із важливих напрямів подальших досліджень у сфері розвитку технологічного базису ЗРО.

razvitija-zarubezhnyh-zrk. 4. Барабанов М. Зенитные ракетные системы: ситуация на мировом рынке, 2010. https://topwar.ru/19-zenitnye-raketnye-sistemy-situaciya-namirovom-rynke.html. 5. Заблоцкий В. "Оборонка" Украины: что сделано и что сделать только предстоит. http://argumentua.com/stati/oboronka-ukrainy-chto-sdelanoi-chto-sdelat-tolko-predstoit. 6. Щит и меч Украины: основные достижения оборонно-промышленного комплекса за 2017 год. Часть III. 7. Буренок В. М. Развитие военных технологий XXI века: проблемы, планирование, реализация / В. М. Буренок, А. А. Ивлев, 
В. Ю. Корчак. - Тверь: Издательство ООО "КУПОЛ", 2009. - 624 с. 8. Буренок В. М. Программно-целевое планирование и управление созданием научнотехнического задела для перспективного и нетрадиционного вооружения / В.М.Буренок, А. А. Ивлев, В. Ю. Корчак. - М.: ИД Граница, 2007. - 408 с. 9. Критические технологии США и стран ЕС. Аналитический обзор. $\mathrm{http} / / /$ textarchive.ru/c-1307239pall.html. 10. Приоритеты зарубежных НИОКР двойного назначения. Отв. ред. Л. В. Панкова, С. Ю. Казеннов. ИМЕМО РАН. $2016.236 \quad$ с https://www.imemo.ru/files/File/ru/publ/2016/2016 039.pdf 11. Евстигнеев В. Состояние и стратегия совместного развития отечественной микроэлектроники и радиоэлектроники //Компоненты и технологии, № 5, 2005г. С. 10-13. 12. Николаев А. И. Совершенствование научно-методического аппарата обоснования состава научно-исследовательских и опытно-конструкторских работ по развитию радиолокационных технологий на основе построения структурных функциональнотехнологических схем перспективных образцов радиолокационного вооружения / А. И. Николаев, А. Д. Юрин, А. И. Полубехин // Вооружение и экономика: электронный журнал.- 2009, № 2 (6). - С. 31-39. 13. Демидов Б. А. Проблемные аспекты развития технологий, ориентированных на создание и применение перспективных средств вооруженной борьбы / Б. А. Демидов, С. И. Хмелевский, О. А. Хмелевская, Т. В. Кулешова // Системы озброення і військова техніка. - 2012. - № 1 (29). - С. 101-109. 14. Величко О. Ф. Критичні технології як нацюнальний пріоритет у забезпеченні обороноздатності держави /О.Ф.Величко, О.І. Затинайко, П.П. Скурський // Наука і оборона, 2011. - №4. - С. 23-30. 15. Болотов Е. Г., Мизрохи Б. Я. Новое поколение зенитных управляемых ракет средней даль-ности // Специальный выпуск журнала «Полет» к 50-летию МКБ «Факел», 2003 г. http://pvo.guns.ru/book/fakel/new_gen.htm.

16. Проектирование зенитных управляемых ракет // Под ред. И.С. Голубева и В.Г. Светлова. М.: Изд-во МАИ, 2001. 732 с. 17. Акопян И. Мозг ракеты: особенности построения и тенденции развития головок самонаведения для ракет класса "поверхность-воздух" и “воздух-воздух". Воздушно-космическая оборона, №3 (28) 2006. http://militaryarticle.ru/voenno-kosmicheskayaoborona/2006/12386-mozg-rakety. 18. Ланецький Б., Чепков I., Лук'янчук В., Ніколаєв І. Структура i тенденції розвитку технологічного базису сучасного зенітного ракетного озброєння середньої та великої дальності / Наука і оборона, № 4, 2013.- с 56-62.

\title{
ПУТИ И ПРИНЦИПЫ РАЗВИТИЯ ТЕХНОЛОГИЧЕСКОГО БАЗИСА ЗЕНИТНОГО РАКЕТНОГО ВООРУЖЕНИЯ
}

\author{
Вадим Владимирович Лукъянчук (кандидат технических наук, с.н.с) ${ }^{1}$ \\ Иван Михайлович Николаев (кандидат технических наук, с.н.с) \\ Павел Викторович Опенько (кандидат технических наук) ${ }^{2}$ \\ Юрий Анатольевич Дзюбенко (кандидт военных наук, доцент) ${ }^{2}$
}

\footnotetext{
${ }^{1}$ Харьковский национальный университет Воздуиных Сил имени Ивана Кожедуба, г. Харьков

${ }^{2}$ Национальный университет обороны Украины имени Ивана Черняховского, Киев, Украина
}

На основе анализа мировых тенденций развития технологий обосновывается структура технологического базиса, необходимого для создания и производства в Украине современных систем (комплексов) зенитного ракетного вооружения. Показано, что основу этого технологического базиса составляет совокупность продуктовых и производственных технологий, описываюших облик составных частей (боевых и технических средств) зенитного ракетного вооружения, имеет сложную структуру и базируется на достижениях научно-технического прогресса в разных областях знаний. Приведены принципы развития технологического базиса и определены критические технологии, развитие которых позволит создать научно-технологические заделы, которые могут быть положены в основу разработки и производства в Украине перспективных систем (комплексов) зенитного ракетного вооружения следующего поколения.

Ключевые слова: зенитное ракетное вооружение; технологический базис; макротехнология; продуктовая технология; производственная технология; критическая технология; научнотехнологический задел.

\section{WAYS AND PRINCIPLES OF DEVELOPMENT OF ANTI-AIRCRAFT MISSILE SYSTEMS TECHNOLOGICAL BASE}

\author{
Vadim Lukyanchuk (Candidate of Technical Sciences, Senior Researcher) ${ }^{1}$ \\ Ivan Nikolaev (Candidate of Technical Sciences, Senior Researcher) ${ }^{1}$ \\ Pavlo Open'ko (Candidate of Technical Sciences) ${ }^{2}$ \\ Yuri Dzubenko (Candidate of Military Sciences, Associate Professor) ${ }^{2}$
}

${ }^{1}$ Kharkiv National University of Air Force named by Ivan Kozhedub, Kharkiv, Ukraine
${ }^{2}$ National Defense University of Ukraine named by Ivan Cherniakhovsky, Kyiv, Ukraine 
On the basis of analysis of world progress of technologies trends the structure of technological base, necessary for creation and production in Ukraine of the modern anti-aircraft missile systems (complexes) is substantiated. It is shown that basis of this technological base is made by the aggregate of food and productive technologies, describing the look of component parts (battle and technical facilities) of anti-aircraft rocket weapons, has a difficult structure and is based on achievements of scientific and technical progress in the different areas of knowledge. Principles over of development of technological base are brought and critical technologies, development of which will allow to create scientifically-technological reserves which can be fixed in basis of development and production in Ukraine of perspective systems (complexes) of the next generation anti-aircraft rocket weapon are presented.

Key words: anti-aircraft missile system; technological base; macrotechnology; food technology; productive technology; critical technology; scientifically-technological reserve.

\section{References}

1. Nenartovych $\mathbf{N}$. Sovremennye zenytnye raketnye systemy PVO y nestrateghycheskoj PRO// Ynformacyonnoanalytycheskoe yzdanye "Vozdushno-kosmycheskaja oborona", 2010. 2. Korovyn A. N. Raketnыe kompleksы PVO: tendencyy razvytyja. https://topwar.ru/2217-raketnyekompleksy-pvo-tendencii-razvitiya.html. 3. Alekseev P., Danylov O. Sostojanye y perspektyvy razvytyja zarubezhnykh ZRK boljshoj y srednej daljnosty // Zarubezhnoe voennoe obozrenye. 2006. № 11. S. 35- 43. http://militaryarticle.ru/zarubezhnoe-voennoe-

obozrenie/2006-zvo/7419-sostojanie-i-perspektivy-razvitijazarubezhnyh-zrk. 4. Barabanov M. Zenytnye raketnye systemy: sytuacyja na myrovom rynke, 2010. https://topwar.ru/19-zenitnye-raketnye-sistemy-situaciya-namirovom-rynke.html. 5. Zablockyj V. "Oboronka" Ukrayny: chto sdelano y chto sdelatj toljko predstoyt. http://argumentua.com/stati/oboronka-ukrainy-chto-sdelanoi-chto-sdelat-tolko-predstoit. 6. Shhyt y mech Ukrayny: osnovnye dostyzhenyja oboronno-promyshlennogho kompleksa za 2017 ghod. Chastj III. 7. Burenok V. M. Razvytye voennыkh tekhnologhyj XXI veka: problemy, planyrovanye, realyzacyja / V. M. Burenok, A. A. Yvlev, V. Ju. Korchak. - Tverj: Yzdateljstvo OOO "KUPOL", 2009. 624 c. 8. Burenok V. M. Proghrammno-celevoe planyrovanye y upravlenye sozdanyem nauchnotekhnycheskogho zadela dlja perspektyvnogho y netradycyonnogho vooruzhenyja / V. M. Burenok, A. A. Yvlev, V. Ju. Korchak. -M.: YD Ghranyca, 2007. - 408 s. 9. Krytycheskye tekhnologhyy SShA y stran ES. Analytycheskyj obzor. http://textarchive.ru/c-1307239pall.html. 10. Pryorytety zarubezhnykh NYOKR dvojnogho naznachenyja. Otv. red. L. V. Pankova, S. Ju. Kazennov. $\begin{array}{lllll}\text { YMJeMO RAN. } & 2016 . & 236 & \text { s. }\end{array}$ https://www.imemo.ru/files/File/ru/publ/2016/2016_039.pdf 11. Evstyghneev V. Sostojanye y strateghyja sovmestnogho razvytyja otechestvennoj mykroelektronyky y radyoelektronyky //Komponenty y tekhnologhyy, №5, 2005. S. 10-13. 12. Nykolaev A. Y. Sovershenstvovanye nauchno- metodycheskogho apparata obosnovanyja sostava nauchnoyssledovateljskykh y opytno-konstruktorskykh rabot po razvytyju radyolokacyonnykh tekhnologhyj na osnove postroenyja strukturnykh funkcyonaljnotekhnologhycheskykh skhem perspektyvnykh obrazcov radyolokacyonnogho vooruzhenyja / A. Y. Nykolaev, A. D. Juryn, A. Y. Polubekhyn // Vooruzhenye y ekonomyka: elektronnyj zhurnal.- 2009, № 2 (6). - S. 31-39. 13. Demydov B. A. Problemnye aspekty razvytyja tekhnologhyj, oryentyrovannykh na sozdanye y prymenenye perspektyvnykh sredstv vooruzhennoj borjby / B. A. Demydov, S. Y. Khmelevskyj, O. A. Khmelevskaja, T. V. Kuleshova // Systemy ozbroennja i vijsjkova tekhnika. 2012. - № 1 (29). - S. 101-109. 14. Velychko O. F. Krytychni tekhnologhiji jak nacjunaljnyj ppiopytet u zabezpechenni oboronozdatnosti derzhavy/O. F. Velychko, O.I. Zatynajko, P.P. Skursjkyj // Nauka i oborona, 2011. \#4. - S. 23-30. 15. Bolotov E., Myzrokhy B. Novoe pokolenye zenytnykh upravljaemыkh raket srednej daljnosty // Specyaljnыj vыpusk zhurnala «Polet» k 50-letyju MKB «Fakel», 2003 gh. http://pvo.guns.ru/book/fakel/new_gen.htm.

16. Proektyrovanye zenytnykh upravljaemykh raket // Pod red. Y.S. Gholubeva y V.Gh. Svetlova. M.: Yzd-vo MAY, 2001. 732 s. 17. Akopjan Y. Mozgh rakety: osobennosty postroenyja y tendencyy razvytyja gholovok samonavedenyja dlja raket klassa "poverkhnostj-vozdukh" y "vozdukh-vozdukh". Vozdushno-kosmycheskaja oborona, \#3 (28) 2006. http://militaryarticle.ru/voennokosmicheskaya-oborona/2006/12386-mozg-rakety.

18. Lanecjkyj B., Chepkov I., Lukjanchuk V., Nikolajev I. Struktura i tendenciji rozvytku tekhnologhichnogho bazysu suchasnogho zenitnogho raketnogho ozbrojennja serednjoji ta velykoji daljnosti / Nauka i oborona, № 4, 2013.- $\quad$ s $56-62$. 